\title{
Reforming Ghana's Electoral Process: Lessons and the Way Forward
}

\author{
Emmanuel Debrah ${ }^{1}$ \\ ${ }^{1}$ Department of Political Science, University of Ghana, Ghana \\ Correspondence: Emmanuel Debrah, Department of Political Science, University of Ghana, Ghana. E-mail: \\ edebrah2001@yahoo.co.uk; ekdebrah@ug.edu.gh
}

Received: October 17, $2014 \quad$ Accepted: October 29, $2014 \quad$ Online Published: January 10, 2015
$\begin{aligned} & \text { doi:10.5539/jpl.v8n1p1 } \\ & \text { URL: http://dx.doi.org/10.5539/jpl.v8n1p1 }\end{aligned}$

\begin{abstract}
This article reviews the electoral reform initiative which began in 1994. It notes that electoral reforms in Ghana have been at the elite's instigation. Hence they have coalesced around elite bargaining and consensus. In 1994, the Inter-party Advisory Committee (IPAC) was inaugurated to fashion new rules of the game to direct the electoral process. The reform settled the elite disagreements over the future of Ghana's democracy, which generated mass and elite confidence in the electoral process. Yet, the reform has failed to address new challenges including fair representation of the people in the legislature/Parliament and uneven playing field caused by the exploitation of incumbency in the use of state resource for campaigns thereby stifling effective inter-party competition. Furthermore, the politics of winner-takes-all has worked to obstruct the capacity of the smaller parties to participate in politics in a fledgling democracy in Africa where inclusive participation is highly recommended. A re-apportionment of constituency boundaries to reflect fair representation and review of the party financing laws to provide opportunity for opposition parties to access resources would deepen Ghana's multiparty politics and democracy.
\end{abstract}

Keywords: political parties, electoral process, reform, constituency, Ghana

\section{Introduction}

Ghana has received praise for promoting "quality" democracy in Africa. It has successfully carried out six peaceful and relatively free and fair elections even though the founding election of 1992 produced a bizarre outcome. Of the six elections, two have produced power alternation in 2000 and 2008. By this standard, some pundits would even score Ghana's democracy as firmly consolidated in the conceptual framework of Huntington (1991) and Dahl (1956). Moreover, the legitimacy of the elections has received overwhelming acknowledgement from the varying actors including the international community and domestic election observers. In all the elections, the losing candidates have conceded defeat within a reasonable time and played their opposition role in and outside the legislature (interview, Dr. Frank Adom, Accra, June 2014). The recorded electoral successes have influenced the performance of other state institutions. For instance, there is a perception that Parliament has not done badly given its limited resources and weak technical capacity (Lindberg, 2010; Gyimah-Boadi, 2004). With the exception of a few politically manipulated legislations with disappointing results such as the XTS (Note 1), Parliament has spearheaded the passage of important legislations including the Disability, Petroleum and National Health Insurance Acts to direct critical areas of popular needs (interview, Prof Mike Oquaye, former deputy Speaker of Parliament and MP, Accra, June 2014). The Judiciary has been relatively robust with the promotion of human rights and administration of justice albeit criticisms over corruption in the adjudication process. The free environment has instigated vibrant media activities and the promotion of human freedom and development (Gyimah-Boadi, 2004: 2).

These notwithstanding, there is a general perception that the electoral process has not been robust to instill voter confidence in the six general elections. Concerns about failed electoral process have been loudly repeated in media commentaries and political platforms. Some of these issues ranged from the winner-takes-all politics, which is believed to be one of the major sources of campaign violence, intolerance and acrimonious politics in Ghana. The electoral discourse further revealed sharp disagreements about the nature of the electoral system that has evolved since 1992. Critics have pointed to institutional, procedural and technical weaknesses in the election processes. In recent media discussions and popular commentaries issues regarding delimitation, system manipulations and collusion of the staff of the election management body have featured prominently (Note 2). These pertinent concerns have implications for achieving credible elections. Yet, there is little or no effort made 
to deal with the roots of the issues involved.

The literature shows that a number of African countries that underwent democratization in the early 1990s have implemented varying electoral process models but little attention has been paid to the question of why the electoral processes went through substantial changes. Whereas in most stable democracies electoral systems have been treated as fixed elements, in Africa, changing the democratic rules of the game has become a growing area for consideration because of systemic, structural and institutional complexities and failures. Yet, in the literature on politics in Ghana, electoral reform is an uncharted territory. But Heraclitus has asserted that everything is in flux under the pressure of shifting situations (Olsen, 2009: 64). Against this backdrop, this article demonstrates why Ghana's electoral process needs to be overhauled if competitive election should be sustained. It then suggests alternative pathways to achieving a credible electoral process for sustainable multiparty democracy in Ghana.

\section{Explaining Electoral Reform}

There is little agreement among scholars about the definite meaning of electoral reform due largely to the nature of elections, which often times exude controversies, tensions and uncertainties (Gallagher et al., 2005: 14). In spite of the seemingly lack of consensus about the definition, Lijphart (1994: 51) noted that the most commonly used definition is that electoral reform is about a 'wholesale replacement of the electoral formulae of national electoral systems'. This implies that reforms in the election process will be detailed and occur in areas such as the formula for sharing seats and other forms of voting calculations. This point is reinforced by Lijphart's (1994: 56) argument that significant reforms refer to any changes that involve the electoral formula or any change of at least 20 percent in district magnitude, legal threshold or assembly size. Lijphart refers to this type of electoral reform as a major one. A minor then is the one involving marginal changes. However, Katz (2007: 308) has observed that there is no clear dividing line between major and minor reforms; even more, there is no clear dividing line between reforms that might be considered minor and trivial. Therefore, it may seem that any change in the (electoral) rules that leads to alteration in the operation of the electoral system connotes electoral reform (Celis et al., 2011). On the other hand, according to the IDEA (2006: 295), it is the improvement of the responsiveness of an electoral process to the desires and expectations of the electorate. It is reform when the change is intended to foster and enhance impartiality, inclusiveness, transparency, integrity or accuracy of the electoral process.

For a long time electoral reform was conceived along Lijphart's model, as a change in the proportionality of an electoral system, i.e., a change in the electoral formula or threshold. It was understood that winning more seats was the key objective for any electoral change initiation or the important consequence of electoral reform - the key issues that matter to voters and politicians alike. However, in the recent discourse of electoral reform, three interrelated dynamics in the process of electoral reform have been delineated. For instance, the IDEA (2006: 295-296) has articulated cogently some of the features around which reforms may take place: the first is the legal framework that governs the conduct of elections. Here, the reform may focus on the amendment of the constitution, the electoral law, and other related regulatory instruments, which aim to foster the integrity of the elections. As Jacobs and Leyenaar (2011: 41) noted, 'a change in the legislation on the electoral processes is an electoral reform'. The motivation for change could be the alteration of the election laws or introduction of rules on voting choices. The second may address administrative processes including new mechanisms and technical innovations to build the capacity of the election management body. The third could be directed at political changes including the environment within which the election body performs its duties in order to create a "safe" haven for it to carry out its responsibilities (IDEA, 2006: 295-296).

Stakeholders that have stakes in elections have a role to play in the reform of any electoral process. In Africa and Ghana in particular, the election management body has been instrumental in the reform efforts. Smith (1960: 1-6) reports that the Electoral Commissions of many Independent African countries responded to perceived shortcomings of the inherited colonial electoral systems by changing the status quo to accommodate the post-colonial political dynamics. For instance, in Ghana, the EC expanded voters' access to registration, and created opportunity for Ghanaians to exercise their franchise (Crabbe, 1975). Politicians and political parties have also featured in the reform agenda. Hence much of the reforms in the electoral process prior to democratization largely occurred as a response to intense pressure from politicians and political parties. For instance, complaints from political parties caused a change in the 1979 constituency seats. Voters as well as recommendations by Constitutional or Presidential Commissions have stimulated electoral changes in many developed and emerging democracies. For instance, the electoral reforms in Italy and Japan in the 1990s have been cited as reforms where the voters' dissatisfaction with the system was the catalyst. In Ghana, it took the Siriboe's Commission Report to re-demarcate constituency boundaries (Siriboe Report, 1968). 


\section{The Theoretical Imperative}

To provide a context for discussing Ghana's electoral process reforms, the paper interrogates several theoretical strands. The dominant theories used to explain electoral reform are the behaviouralist or rational choice and institutionalist or sociological approaches. The earliest model for analyzing electoral reform came from the rationalists. The rational choice approach to electoral reform coalesce around three key principles namely the optimization, outcome-contingent motivation and information seeking (Benoit, 2004: 374; Shugart, 2008; Renwick, 2010; Katz, 2007). According to this model, electoral reform is a political process in which authoritative decision-makers effect changes in the electoral system in order to achieve their own political benefits. The model views politicians as maximizing political power in order to enhance their party's chances of winning general elections (Shugart, 2008). In this case, the elite reform the electoral process based on their strategic calculations to minimize possible losses (Benoit, 2004: 376). It may therefore appear that electoral reform will address critical areas that are of great concern to politicians rather than an exercise geared towards achieving fairness of votes and allocation of seats in the polity or anticipated changes in the population such as population growth dynamics in oil extraction areas (see Renwick, 2010). Because political elites seek to implement electoral reforms that will serve their interest (Benoit, 2004: 373), Hindmoor (2006: 190-192) noted that they actively search for vital information about the consequences of the reforms in order to gather as much information as possible about the range of reform options and their consequences on their prospect for winning more seats.

In recent times, however, the rational choice model has come under incessant attack on several grounds. It has been asked why politicians would change the rules of a game they are convinced of winning (Katz, 2007:308)? Besides, it has been argued that politically-motivated electoral reforms can be counterproductive due to the high degree of uncertainty in their effects on the fortunes of the political actors (Colomer, 2005: 22). Indeed, some scholars have claimed that due to uncertainty about the effect that the act of reform may have on the fortunes of politicians, parties that are likely to suffer damages would resist the change (Reed and Thies, 2001). Furthermore, it has been observed that only political parties that feel most dissatisfied with the rules in use (for instance, parties relegated to opposition for several years) would support a change in the electoral system (Pilet \& Bol, 2011: 67). Other commentators have opined that states tend to pursue electoral reforms as 'an elite response to popular demands for new forms of participation' (Donovan \& Karp, 2006: 672). Hence, it has been contended that anytime the electorate perceives a particular reform proposal to be antagonistic to their interest, they would react against the initiative. In order to prevent the political system from collapse, the elite would implement electoral reform by accommodating popular demands.

In response to the weaknesses of the rational choice model some scholars have propounded and deployed the institutionalist paradigm to explain why electoral reforms would be convoked. This approach focuses on the interrelationship of institutions and their societal roots (Lijphart, 1994). The core of the institutionalists' argument is that the institutional setting of any polity is relatively stable. It is only in situations of extreme exogenous shocks that the institutional equilibrium will be distorted. Thus, unlike the rational choice framework, the institutionalists believe that reforms are likely to occur against the backdrop of institutional dysfunctions, i.e., when existing institutions produce perverse effects (Shugart, 2008: 2). For instance, Katz (2007) observed that there are possibilities of system changes when the existing electoral arrangements suffer erosion due largely to concerns such as vote-buying and nepotism. Thus, according to the advocates of this model, electoral reform occurs as a result of perceived imbalance in the established arrangement for conducting elections. Hence, the IDEA (2006: 296) explained that reforms to an electoral process may be triggered by the failure to deliver acceptable elections or by conflict resulting from disputed elections and or by recognized changing dynamics related to population growth and increased economic activities.

Beyond the rational choice and institutionalist models, some scholars have explored other means of explaining reform. For instance, it has been claimed that the desire to adopt best international practice can instigate minor or major electoral reform. Hence, Bowler and Farrell (2009) analyzed the contagion effect situation, which views electoral reform as part of a package of general democratization initiative. In other words, electoral reform has been linked to donor conditionality for the transition from authoritarian rule to a democracy. For instance, countries that depended on international donors' financial support including several African countries were forced to implement electoral reform as part of the overall political reforms to inaugurate the rebirth of liberal democracy such as was witnessed in Liberia and Sierra Leone - that emerged from civil war to democracy. Dalton and Gray (2003) then identified "diffusion agents" as a factor that instigates progressive electoral reforms. For instance, their study found a clear diffusion of democratic reform across 18 advanced democracies made possible through the sharing of strategic information among OECD and the EU member-states, which led to the 
expansion of the electoral marketplace. Also, it has been observed that unique events rather than political forces could potentially cause electoral reform.

There is a new thinking that claims that the varying models are not diametrically opposed to each other rather, they are complimentary. For instance, it has been argued by the sociological institutionalists that electoral system reforms do not just happen rather they result from the deliberate actions of the political elites. Yet, the politicians prefer to forge close interactions with popular opinion in order to arrive at a decision about the content of the reform (Blau, 2008: 12). Thus, it is likely that both voters and politicians will subject any electoral reform initiative to cost-benefit analysis before throwing their weights behind it (Renwick, 2010; Dong-Yoon \& Sang Hwa, 2004).

\section{The Method}

Much of the empirical works on Ghana's elections deployed the quantitative approach to explain the mechanics of the elections and their outcomes (Ayee, 1998, 2001; Boafo-Authur, 2006). However, this study departs from the conventional method and leaned on the qualitative research design because the nature of inquiry of this study involved interpretations, inferences and opinions rather than figures (Bryman, 2012: 380). Hence 60 key informants representing differing perspectives were chosen and engaged in face-to-face interviews using largely semi-structured interview guide from June to July 2014. In order to obtain the views of the architects of the electoral reform project, the researcher adopted the purposive sampling method which ensured that 10 staff of the Electoral Commission (EC), 16 political parties' officials comprising 5 each from the National Democratic Congress (NDC) and New Patriotic Party (NPP) (that had alternated power), and 3 each from the Convention People's Party (CPP) and People National Convention (PNC) (that had been in opposition throughout the period) were chosen for interviews. These are parties that have participated in all the six elections and won parliamentary seats and have relatively organized structures in the 10 regions and constituencies. Only party officials that have represented their parties on the Inter-party Advisory Committee (IPAC) were singled out for interview because they were privy to the discussions that had taken place at the forum. Two Members of Parliament (MPs), each representing the four political parties were randomly picked from the published lists of MPs at Parliament for interviews.

The remaining 26 of the respondents were ordinary voters randomly selected from the voters' register at the headquarters of the EC. To achieve this, four constituencies that are located in the Accra Metropolitan Assembly (AMA) and have voting population between 70, 000 and 180,000 were chosen. Through this method, Okaikoi North, Dome-kwabenya, Ayawaso West-Wuogon and Dade Kotopon constituencies were picked. Due to the lack of funding for this project, all respondents were chosen from Accra, the administrative capital and the location of the headquarters of the EC and the political parties. Accra is also the macrocosm of the electoral population - it possesses ethnic and socio-political complexion of the electorate and the elite. In addition, the researcher undertook an extensive review of the literature and the theoretical imperatives of electoral process and reforms from authoritative sources drawn from journals, books, and others. Part of the analysis of the study involved using the primary data to validate some of the claims in the secondary data/literature, thereby enhancing our understanding of the contribution this study makes to the literature on electoral reform and party politics.

\section{The Legal Context of the Electoral Process}

Ghana's electoral process is well grounded in legislations. Prior to the coming into force of the 1992 Constitution, the Representation of the Peoples Law, 1992 (PNDCL 284) defined the scope and practice of the electoral process and system. It was the main legislative instrument that governed the management of the electoral process used for the 1992 transitional elections. The PNDCL 284 regulated the delimitation of constituencies and the mechanics for managing the elections including qualification of voters and candidates, appointment of election staff, filing of nominations and management of post-election petitions (Republic of Ghana 1992a: 1-25).

However, the 1992 Constitution provides the legal framework for managing the post-democratization electoral process. Within the context of the Constitution, a number of Legislative Instruments and Constitutional Instruments have been developed to regulate election activities. Chapter Seven of the Constitution provides detailed rules on electoral conduct, political parties' activities, voters' rights and responsibilities of the Electoral Commission (EC) (Republic of Ghana 1992b: 102). The Public Election Regulations Constitutional Instrument (C.I 15) was enacted to guide the creation of constituencies for the 1996 parliamentary elections. New guidelines for party politics called Political Parties Act 574 passed in 2000 provided direction for the political parties. It stipulated specific rules regarding political party registration, internal organization and financing (Republic of Ghana 2000:1-16). In addition, the Representative of the People (Parliamentary Constituencies) Instrument (C.I.46) was passed in 2004 to determine the creation of new constituency seats. By 2012, it has become evident 
that the existing legal framework needed refinement because of challenges posed by the elite disagreements over the integrity of the electoral instruments. Hence, the Public Elections (Registration of Voters) Regulations (C.I.72) and C.I 75 were created. The C.I. 72 and C.I. 75 changed the dynamics of the electoral process because they introduced biometric system for voter registration and voting (see Republic of Ghana 2012a: 1-21).

\section{Past Electoral Reform Initiatives}

Concerns for electoral reform have not only become fashionable in recent times. After the overthrow of Nkrumah's Convention People's Party (CPP), the military junta set up the Siriboe's Commission to implement electoral reforms. The Commission's Report led to a paradigm shift from the practice where a Minister was assigned the responsibility for managing elections (Siriboe Report 1968: 3). Indeed, the Electoral Provisions Act, 1965 (Act 291) and the Electoral Provisions (Registration) Regulations, 1958 gave the Minister of Local Government the power to appoint election staff and register voters (Republic of Ghana 1965). The 1969 Constitution, however, altered the electoral laws and ushered in the independent electoral commission model because the old system was found to be prune to political manipulations and rigging of elections (Republic of Ghana 1969).

The most recent electoral reform has occurred both as elite imposition and elite settlement (interview, Dr Tweneboa, Accra, July 2014). It began in 1994 after the controversial 1992 founding elections. The opposition parties that lost the November 1992 presidential election and boycotted the subsequent parliamentary polls in December of the same year, threatened to stay away from participating in all future elections unless there was a satisfactory electoral reform. The politically-charged environment did not only pose danger to the survival of the electoral institution that had been inaugurated in March 1993 but also the democratic foundation since it depended on the holding of successful elections (interview, Ofosu Asamoah, MP for Kade, Accra June 2014). The opposition parties charged that the electoral system and process used for the 1992 election gave untrammeled advantage to the National Democratic Congress (NDC). Led by the New Patriotic Party (NPP), the opposition parties launched the "Stolen Verdict' (a compendium of electoral fraud) purported to have been committed against opposition parties by agents of the NDC and the Interim National Electoral Commission (INEC) during the election (NPP, 1993; Boahen, 1996).

The NPP gave out a litany of instances of election violence perpetrated against its candidates and officials. All the opposition forces then laid out stringent conditions that must be met before returning to the electoral front (interview, John Boadu, NPP Organizer, Accra, July 2014). They insisted that the electoral process should be overhauled by (i) creating a transitional body to supervise the electoral process (ii) compiling a completely new voters' roll and identity cards for voters, and (iii) replacing the INEC with a new body with representatives from all the parties (NPP, 1993: 28-30; Ayee 1998). On the other hand, the NDC saw the prevailing electoral process as efficient and therefore made no electoral change demands. According to the NDC, the status quo had not posed any threat to the credibility of the 1992 elections because the international community led by the Commonwealth Secretariat's team of election observers endorsed the election outcome as free and fair (interview, Gyan-Tutu, NDC MP for Tain, Accra, July 2014).

With the future of democracy threatened and survival of the electoral process hanging in a balance, the international community pressured the EC for electoral reform as the only prudent initiative to save Ghana from slipping into the state collapse syndrome (interview, Cecilia Akrofi, Teacher, Accra, July 2014). In countries that staked to the status quo such as Ivory Coast, Mali, Kenya and Central Africa Republic, disagreements over the electoral process and elections' outcome sparked heinous civil wars (Lumumba-Kasongo, 2005:1-20). Knowing that the reform has great potential for democratic progress, the International Foundation for Electoral System (IFES) established a presence in Ghana to provide technical guide towards electoral reform (interview, Kofi Arhin former EC Director of Election, Accra, June 2014). Other international agencies such as the Commonwealth Secretariat and National Democratic Institute and their governments pledged both material and financial support to implement changes in the electoral process (Badu and Larvie 1996; Ayee 1998). The favourable international backing for reform encouraged the elite settlement. Both the NDC and NPP agreed to proceed by broad consensus to enact a new system that would promote the general good (Tsebelis, 2002:33). As a result, in March 1994, an elite consensus body called the Inter-party Advisory Committee (IPAC) was inaugurated. It comprised the EC that had been established by Act 451 in 1993, representatives of the political parties, and donors as observers (ex-officio members) (interview, PNC Dade Kotopon Constituency Chairman, Accra, June 2014). However, when IPAC commenced work, it functioned as a chamber for the elite bargain over how to make the electoral process achieve its objective of free and fair elections. The elite used the IPAC platform to reform the electoral process through agreement among themselves on the thorny areas of the electoral process (interview, NDC MP for Dome Kwabenya, Accra, June 2014). Indeed, rather than acting 
against each other, they recognized that they share the same interest in the system (Aardal, 2002: 1).

A major change in the electoral process instigated via the elite consensus platform was the replacement of the voters' roll. The politicians agreed that the voters' register used for the 1992 elections was inaccurate, outdated, unacceptable and therefore incapable of promoting free and fair elections in the future (Ayee, 1998: 47; Commonwealth Secretariat 1992). The registration of voters departed from the old method where names of voters also bore titles such as "Nana", "Dr/Prof/Mr. and Rev/Alhaji if they were traditional rulers, academics and religious leaders respectively (see Commonwealth Secretariat 1992: 18). The mechanics of the electoral roll/ register were also overhauled to ensure the use of a combination of thumbprint and photo Identity (ID) cards in the less controversial areas and controversial border towns respectively (interview, NDC MP for Dade-Kotopon, Accra, June 2014). In order to promote high integrity of the register, recruited temporary registration officials and agents of the political parties underwent thorough training on the rules of the game. Parties' agents formed integral part of the registration process. As observers of the process for their parties, they could challenge a suspected ineligible applicant who came to register at the centres (interview, Kwabena Bonfeh, former CPP Organizer, Accra, July 2014).

A Registration Review Committee (RRC) with presence in all constituencies was composed to arbitrate disputed registration cases. Individuals who felt aggrieved by the decision of the RRC could appeal to the courts for redress. A provisional voters' roll was then outdoored for inspection by those who registered their names for purposes of rectifying any anomaly such as omissions, wrong inclusions and purging off names of the deceased (interview, Adarkwa Yiadom former EC Director, Accra, July 2014). The parties' agents were also permitted to endorse the daily records of the registration exercise at the centers. The EC submitted the final register to each political party to aid their door-to-door campaigns. Every year, the EC has endeavoured to add new qualified voters on the roll even though it has implemented this mandate more in the election years. By 2000 , every registered voter had been issued with a photo ID card. In 2004, changes in the process saw the photographs of voters appearing on the register alongside their vital information. This measure aided the smooth identification of the voter thereby dispelling the fears of double voting and impersonation (interview, Fred Teteh, EC Accra, 2014).

An important dimension of the reform was the replacement of the translucent/opaque ballot boxes used for the 1992 elections with transparent boxes. Cardboard screens were set up in open spaces designated as polling centers where voters entered to make their decisions before depositing their thumb-printed ballot papers in the box - located at conspicuous places in front of some designated public buildings marked as polling centers (interviews, former NDC Deputy General-Secretary Accra, July 2014). This was a deviation from past practices where voters went to a closed room to mark their choice of candidates. This situation stirred allegations that some voters concealed additional ballot papers on their body when they went to the "dark rooms" to choose their candidates (Ayee, 1998; Debrah 2011). Therefore, by setting up the polling booths in open places, the countless rumours and allegations of vote rigging virtually abated. In order to allay popular fears about doctoring of figures during and after vote-counting at the polling stations, the Legislative Instrument was amended, which allowed counting of votes and declaration of results to take place at the polling centers immediately voting ended (Electoral Commission 1996:2-16). In the presence of candidates' agents and voters, the Presiding Officers loudly counted the ballots for each candidate and recorded the figures on the Declaration of Result Form, which each party/candidate agent countersigned to authenticate the results. Each agent was given a copy of the signed Form for the candidates' independent vote-tabulation (interview with PNC and CPP General Secretaries, Accra, June 2014). At the Regional Offices of the EC where constituency cumulative results for each candidate were faxed to the headquarters, the candidates' agents witnessed the process (Electoral Commission 2008: 1-16).

In recent times, the use of biometric system has become trendy in many African countries that have carried electoral reforms. For instance, since 2000, Nigeria and South Africa's elections have incorporated the use of biometric registration and voting into their electoral process. Confronted by persistent concerns of vote rigging including double-voting and impersonation, the political actors clamoured for a full proof electoral process to seal the holes. In consequence, a biometric registration and voting was grafted onto the electoral process in 2012 - a radical departure from the elections' norms and practices (Republic of Ghana 2012a:1-16). The EC and other stakeholders in the election were convinced that the introduction of biometric registration and voting verification would halt fraud and other abuses in the electoral process and thereby enhance the credibility of the elections and their outcome. Hence, the slogan, "no verification no vote", was loudly echoed in the media and the political parties' campaign platforms to signal the end to election fraud? (Note 3)

The reform has also focused on party organization and financing. The goal of party reform hinged on the need to provide a leveled playing field for political competition (interview, EC Director of Research, Accra, June 2014). 
By 2000, it had become obvious that the Political Parties Law (PNDCL 281) was no longer capable of aiding party development. Indeed, the Law was obstructive to competitive party politics and democratic progress (Ayee 1998:31). As a result, a new Political Parties Act 574 was enacted in 2000 to replace the PNDCL 281 in order to guarantee greater citizens' participation in politics. Only parties with multi-ethnic complexion and whose internal organization conformed to democratic ethos qualified to receive the Certificate of Registration to participate in any electoral competition (interview, PNC Organizer, Accra, July 2014). In order to discourage political corruption, political parties were requested to make a declaration of their assets and expenditure within 90 days after receipt of the final Certificate of Registration, and 21 days before general elections respectively. Similarly, within six-months from $31^{\text {st }}$ of December of each year, and after a general election or by-election in which a party participated, a detailed audited statement of accounts (showing income and expenditure) should be submitted to the EC for scrutiny (Republic of Ghana 2000a: 1-13).

Party financing has always been a thorny issue in Ghana's multiparty politics. Incumbents have always been accused of stifling opposition competitors of the oxygen of funds while it used State resources to secure re-election thereby undermining the competitiveness of the elections (interview, Monica Akwei, Accra, July 2014). The PNDCL 281 had disqualified foreign companies from donating to political parties, and limited members' contribution to 200 (\$60) (Republic of Ghana, 1992:3). However, Act 574 scrapped the limited contribution provision and granted to party founding members, unlimited financial donations towards the development of their parties (interview, NPP MP for Okaikoi North, Accra June 2014). In addition, firms owned by Ghanaians could donate to political parties. Only the ban on foreigners' contribution to political parties was retained in the new Law (Republic of Ghana 2000:8-10).

\section{Prevailing Reform Deficits}

Achieving credible elections in emerging democracies has always been a difficult task. While it is true that Ghana's electoral process has undergone significant changes, there are growing popular concerns that, it is still prone to abuses (interview, Mrs Alice Owusu, Banker, Accra, June 2014). One of the lingering issues waiting for attention concerns allegations of gerry-meandering - a practice of mal-apportionment of electoral constituencies to favour one candidate or party. For a long time, many people have complained that realignments of constituencies that had led to the creation of new ones were deliberately planned by the incumbent to disadvantage its opponents (Smith 2011: 1-18). For instance, the opposition parties had alleged that the creation of additional constituencies in 2008 and 2012 were done to enhance the incumbent's chances of winning majority seats in the Legislature. (Note 4) The critics contended that in most densely populated constituencies in the cities including Kumasi, Accra, Takoradi, and Tamale, among others, where the government realized it had a solid majority of support, the boundaries were redrawn in a manner that ensured that some polling stations in the government strongholds were taken to the adjunct locations where the incumbent needed a few votes to win over the opposition parties. (Note 5)

The problem of mal-apportionment of electoral constituencies has led to a situation where one Member of Parliament (MP) represents large numbers of inhabitants (interview, NPP MP for Kade, Accra, June 2014). For instance, in the Ashanti Region, Suame has 90, 305 voters and Oforikrom 109, 597 voters, and in the Volta Region, Ketu South has 126,659 voters. By contrast, there are 22,768 voters in the Krachi West of the Volta and 34,040 voters in Juaben constituency in the Ashanti region, which are also represented by one MP (see Republic of Ghana 2008 and 2012b). The trend in the parliamentary elections further shows that in some constituencies, the votes obtained by the first runners-up were more than what another candidate obtained to win in a nearby/adjunct constituency (interview, CPP Organizer, Accra, June 2014). For instance, the results for the 2008 parliamentary elections in Manhyia show that the NPP and NDC candidates obtained 65,978 and 17, 327 respectively. Similarly, in Asawase constituency, the NPP candidate had 27,168 votes while the NDC obtained 36, 557 votes. Yet, in the neighbouring Ejura-Sekyedumase, the NDC won with 20,038 votes as against 17,312 votes for the NPP (Republic of Ghana 2008:2-6). Similarly, in the 2012 parliamentary election result for Adansi Asokwa constituency, the NDC candidate polled 14,157 votes while the NPP candidate got 15,796 votes. Yet, in the adjunct Obuasi West Constituency, the losing NDC candidate obtained 16,253 votes while the NPP candidate won with 31,101 votes. At Atwima Mponua the story is the same: the NDC candidate had 24,872 votes as against 33,961 votes for the NPP candidate. In several constituencies in other regions, candidates won with lesser voters compared with what the losers obtained at elsewhere. For instance, in Upper West, the NDC candidates won as follows: Wa West, 10,468 votes, Nadowli West, 4,789 votes, Sissala West, 6,001 votes while the losing NPP candidate had 5,527 votes, and in Lambusshie, the NDC candidate polled 6,513 as against 4,792 for the NPP (see Republic of Ghana 2012b: 1-52). The above scenarios have raised much criticism about the fairness of the electoral system and process. It has revealed how the mal-apportionment of the constituencies has created 
inequitable representation to the extent that there are some constituencies where the people are underrepresented while others are overrepresented in the legislature (interview, Mumuni Nasiru, PNC Constituency Chairman, Accra, June 2014).

Perhaps the most critical area of the electoral process where citizens expect changes is the majority system because it has bred the much hated "winner-takes-all" politics (interview, Peter Siaw, Accra, July 2014). Since independence, Ghana's electoral system has been structured along the majoritarian system in which only one Member of Parliament is elected from a constituency (see Republic of Ghana 1992b: 39). The system has run on the principle that in an electoral competition, the most qualified person should be selected to represent a constituency (see Lijphart, 1994:7). However, the system has denied small parties the chance to win any election in a constituency (interviews, CPP and PNC Constituency Chairmen, Accra, June 2014). Given that most constituencies in Ghana have large voting populations sometimes in the range of between $90,000-130,000$ registered voters, there has been no chance for the candidates of the small parties (see Republic of Ghana 2000b, 2008 and 2012b). This situation has made the outcome of elections in these constituencies predictable. While the system, at least, has promoted stable majority in parliament for the ruling government, it has the potential for undermining a pluralistic democratic system because voters of the losing candidates have always felt that they have not been effectively represented. (Note 6) The situation is worsened by the fact that in Ghana as in many African countries that have been engulfed in patronage politics, members of the smaller parties have been relegated to the background because they have had no share in the distribution of the patronage pie to the ruling parties' supporters (interviews, Ahmed Bukari and Jonas Larbi, Accra July 2014; also see Lindberg 2010; Sandbrook and Olbeum 1999).

The electoral process further suffers from the unleveled playing field conundrum. The absence of a leveled playing field in the electoral process has meant that opposition parties and candidates have been treated unfairly in relation to the incumbent (interview, MP for Wenchi, Accra, July 2014). What is true about the electoral process is that it has promoted the ruling party's advantage over the opposition parties (interview, Asumah Matilda, Accra June 2014). For instance, the system has not faulted the incumbent anytime he used state resources to support his election campaigns (interview, Bismarck Akorful, Accra, June 2014). Since 1992, it is common place that incumbent Presidents have scheduled state programs to coincide with their own election campaigns thereby making it difficult to distinguish between state activities and party programs (see GII, et al., 2013:10-24). For instance, incumbent presidential candidates have used public platforms to launch their partisan campaigns (interviews, CPP and PNC Chairmen, Accra, July 2014). While this political behavior has promoted incumbents' election campaigns, it has frustrated the opposition parties thereby causing tension and acrimony in the campaign process. One strategy the ruling party has adopted which has not received any sanction from the EC is the periodic distribution of state largesse to attract opposition parties' supporters (interview, Dr Sandra Mensah, Accra, July 2014). As a result, the phenomenon of mass defections from opposition parties to the ruling party has been a recurrent feature of the election campaign process because the ruling party's patronage bait looked too attractive to be resisted by the opposition supporters (interview, CPP organizer, Accra, July 2014). Similarly, the exploitation of patronage politics has encouraged local companies to draw closer to the government by making donations to the ruling party while shunning the opposition parties. In order to avert government victimization, some donors have made secret donations to opposition parties (see Ayee, Anebo and Debrah 2007:10-20). For instance, throughout the 1990s, Rawlings persecuted Mr. Appiah Menka and others by ensuring that his company Apeno folded up because of the perception that he funded the NPP (Note 7) even though the government claimed that he defaulted in tax payment.

\section{Towards an Efficient Electoral Process}

It is expected that post-democratization electoral reform in Ghana would proceed to guarantee citizens including minority, vulnerable and disadvantaged social groups' free participation and competition in elections. Hence, it is time to overhaul the constituency structure to reflect fair representation of the people. A re-delimitation of constituency boundaries would have to ensure that a fairly equal number of inhabitants are assigned to an electoral unit (interview, NPP MP for Kade, Accra, June 2014). This can be achieved if closely knit villages and small towns are grouped to form a single constituency and large cities are divided into several constituencies. (Note 8) One weakness inherent in the current arrangement is the attempt to apportion electoral boundaries based on cultural, customs, linguistics and land mass considerations, which have reinforced ethnic divisions and exposed electoral activities to violence (interview, Stephen Buah, Media anchor, Accra, July 2014). Since constituencies are designed to produce citizens' political representation, the basic criterion to consider in the delimitation of constituencies should not be territorial/landmarks but rather population quota (interview, Dr Kofi Opuni, Lecturer, Accra, July 2014; also see Smith 2011). It is worth noting that the population criterion is 
consistent with previously demarcated electoral boundaries during and after the demise of British colonial rule. For instance, in delimiting the 103 electoral constituencies, the Van Lare Commission of 1953 depended solely on human population for the allocation of National Assembly seats to the Regions (see Siriboe Report 1968: 55). Even the Siriboe Report, while paying attention to physical features placed much emphasis on population in the demarcation of the 140 legislative seats in 1969. For instance, it assigned a weight of 10 percent to both landmass and population and distributed the constituency seats between the nine regions in the ratio of one point for land mass and nine points for population (Siriboe Report 1968: 56).

Ghana may adopt and adapt to models found in some advanced democratic societies such as Germany and Australia, and emulate South Africa's example. Thus, instead of the proportional representation system, which encourages multiplicity of small parties, which can threaten political stability, the functional constituency (Note 9) approach may be explored to address the imbalances in the current winner-takes-all practice (see Shiu-Hing \& Wing-Yat 2010: 102). While this proposal takes its roots from the Hong Kong model (see notes 8), it is far from a system intended to recognize the contributions of certain occupational and professional groups to Ghana's economy and society and cater for their parochial interest in national decision-making. (Note 10) On the contrary, in the case of Ghana, the functional constituency model seeks to provide opportunity for vulnerable and disadvantaged groups to have their perspectives and interests reflected in policy-making. (Note 11) Due to the generally lack of clear and impartial criteria in deciding the groups that must be represented, and to avoid arbitrariness in the exercise of choice of the groups, IPAC may advance basic criteria that will determine the qualification of the groups. For instance, the requirement may include the relative importance of the group in the society, its political neutrality, loyalty to the state, background of the membership and having multiethnic complexion. For purposes of clarity, organized women, disability associations and youth groups rather than not-for-profit, faith-based organizations, organized labour, chamber of mines and commerce could be scrutinized by the EC for accreditation to participate in the election of their representatives to parliament. (Note 12) Once the groups have been determined, it will run its internal campaign to elect a candidate from among its membership to Parliament. The avenue created under the model will not only inspire the youth and women to participate in politics but could also reduce youth-related violence and crime (interview, the parties' youth activists at Legon, Accra, June 2014). Also by providing opportunity for previously underprivileged groups representing diverse elements of society to take part in national decision-making, it could be the most profound visible policy to deal with the challenge of inequality in representation in Ghana's democracy (interviews, Martha Asabea church elder and Philip Adu Pastor, Accra, July, 2014).

There is no dispute that an Independent Election Commission is a prerequisite for guaranteeing free and fair elections. One of the ways of promoting this idea is to discourage the appointment of the members by the ruling government. (Note 13) A system that allows the President of the country to solely appoint members of the EC as in Ghana has been a source of mistrust, suspicion and inter-party conflicts (Debran, 2011: 17). If the members of the EC are appointees of the President, then it will be foolhardy to conclude on their absolute neutrality and independence. Hence in Ghana, opposition parties have consistently alleged that the EC 'cooperates with the government' (NPP, 1993; Oquaye, 1995; Gyimah-Boadi, 1999). To overcome this hurdle, members should be composed from eminent jurists because throughout the history of democracy, it is only the judiciary that enjoys mass support as an institution inhabited with "neutral and independent minds" (Goodwin-Gill, 1994: 5). By allowing nonpartisan groups rather than political parties or a partisan President to choose the members of the EC from the bench based on a review of their works and proven track records by a judicial committee with international jurists as observers, an objective selection may be achieved (interviews, Atta Coffie and Mary Foah, Lawyers, Accra, June 2014).

There is also no question about the fact that political parties play a key role in creating political solutions in modern societies. Some scholars have noted that having more parties rather than two will auger well for vibrant multiparty politics in emerging democracies because it encourages the creation of better ideas (Satori, 1976; Salih \& Nordlund, 2007). In order to encourage competitive multiparty system, which guarantees freedom and fairness of all parties to participate in the electoral process, they need to be resourced (interview, parties' officials, Accra, June 2014). While not advocating state funding for political parties because there are competing needs for social service expansion to most deprived communities (GII, et al., 2005: 5), it is necessary to level the terrain of campaign financing so that opposition parties can stay in the competition (see Saffu, 2003: 24). In the absence of state funding, the campaign financing laws should be flexible to make it less cumbersome for the opposition parties to raise their independent campaign funds. Election laws that tighten regulations on campaign financing as well as EC's proactive actions to sanction violations of campaign funding laws can help discourage the exploitation of incumbency in campaign financing (interviews, PNC and CPP officials, Accra, July 2014). 


\section{Conclusion}

This paper has articulated why electoral process reform is necessary for the advancement of Ghana's democracy. Electoral reform in Ghana has served as the focal point for the overwhelming wave of successful elections and democratic stabilization in contrast to elsewhere in Africa where there is growing ill-feeling of election failures that had led to ethnic crashes and general political violence. It is worthy of note that the drive for electoral process reforms in Ghana was carefully framed as a way to improve the transparency and integrity of the elections outcome.

Successful electoral reform in Ghana has shown that there is potential effect of structural and institutional changes on competitive and peaceful elections. It has revealed how political parties can cohabitate with an Independent Election Management Body in a collaborative relationship without each destabilizing the other. This positive relationship between the political parties and the EC has given the impetus for further considerations for radical reforms to address the remaining imbalances in the electoral process. Given that electoral reforms are geared towards promoting fairness in competition, prospective reforms are expected to respond to the issue of inclusive representation which fits into the dynamics and trends in society. In other words, future reforms could target key electoral issues such as electoral participation and representation of previously neglected/marginalized groups including policies to reduce gender imbalance in representation, as well as improvement in the independence of the EC. While consolidating the prevailing reform areas, the integrity of the electoral process could be enhanced if consideration is given to improvement in the technical, technological mechanics, procurement and employment processes as well as voter registration systems, voting and vote-counting methods.

\section{References}

Aardal, B. (2002). Electoral systems in Norway. In B. Grofman, \& A. Lijphart. (Eds.), The evolution of electoral and party systems in the Nordic countries (pp. 167-224). New York: Agathon.

Ayee, J. R. (Ed.). (1998). The 1996 General elections and democratic consolidation in Ghana. Accra: Department of Political Science.

Ayee, J. R. (Ed.). (2001). Deepening democracy in Ghana: the politics of 2000 elections (Vol. 2). Accra: Freedom Publications/Department of Political Science.

Ayee, J. R. A., Anebo, F. K., \& Debrah, E. (2007). Financing political parties in Ghana. Dakar: CODESRIA/Consortium of Development Partners.

Badu, K. A., \& Larvie, J. (1996). Elections in Ghana, 1996 Part I. Accra, Ghana: Gold Type Lt.

Benoit, K. (2004). Models of electoral system change. Electoral Studies, 23(3), 363-389. http://dx.doi.org/10.1016/S0261-3794(03)00020-9

Blau, A. (2008). Electoral reform in the UK: A veto player analysis'. In A. Blais (Ed.), To keep or to change first past the post? The politics of electoral reform (pp. 61-89). Oxford: Oxford University Press. http://dx.doi.org/10.1093/acprof:oso/9780199539390.003.0003

Boahen, A. A. (1996). A note on the Ghanaian elections. African Affairs, 85, 277-280.

Bowler, S., \& David, F. M. (2009). Approaches to the Study of Electoral System Design: Devils, Details and "Experts". Paper presented at the ECPR Joint Sessions of Workshops. Portugal: University of Lisbon.

Celis, K., Krook, M. L., \& Meier, P. (2011). The rise of gender quota laws: Expanding the spectrum of determinants for electoral reform. West European Politics, 34(3), 514-530. http://dx.doi.org/10.1080/01402382.2011.555981

Colomer, M. J. (2005). It's parties that choose electoral systems (or, Duverger's Laws Upside Down). Political Studies, 53(1), 1-21. http://dx.doi.org/10.1111/j.1467-9248.2005.00514.x

Commonwealth Secretariat. (1992). The presidential elections in Ghana, 3 November 1992. London: Report of the Commonwealth Observer Group.

Crabbe, C. V. R. A. (1975). The electoral commission. In L. Robin \& A. Dennis (Eds.), Politicians and soldiers in Ghana 1966-1972. London: Frank Cass Publishers.

Dahl, R. A. (1956). Preface to democratic theory. Chicago: University of Chicago.

Dalton, J. R., \& Gray, M. (2003). Expanding the Electoral Market Place. In B. E. Cain, R. J. Dalton, \& S. E. Scarrow (Eds.), Democracy transformed: Expanding political opportunities in advanced industrial democracies (pp. 23-43). Oxford: Oxford University Press. http://dx.doi.org/10.1093/0199264996.003.0002 
Debrah, E. (2011). Measuring governance institutions' success in Ghana: The case of the electoral commission, 1993 - 2008. African Studies, 70(1), 25-46. http://dx.doi.org/10.1080/00020184.2011.557573

Donovan, T., \& Karp Jeffrey, A. (2006). Popular support for direct democracy. Party Politics, 12(5), $671-688$. http://dx.doi.org/10.1177/1354068806066793

Electoral Commission. (1996). Election officials manual. Accra: EC.

Electoral Commission. (2008). Election officials manual. Accra: EC.

Gallagher, M., \& Mitchell, P. (2005). The Politics of Electoral Systems. Oxford: Oxford University Press. http://dx.doi.org/10.1093/0199257566.001.0001

GII, GACC, \& CDD. (2013). Monitoring Abuses of Incumbency in Ghana's 2012 elections. Accra: CDD.

Goodwin-Gill, G. S. (1994). Fee and Fair Elections: International Law and Practice. Geneva: Inter-Parliamentary Union.

Gyimah-Boadi, E. (Ed.). (2004). Democratic Reforms in Ghana: the Quality of Progress. Boulder, Colorado: Lynne Reinner.

Hindmoor, A. (2006). Rational Choice. Basingstoke: Palgrave Macmillan.

Huntington, S. P. (1991). Democracy's Third Wave. Journal of Democracy, 2(2), 12-34. http://dx.doi.org/10.1353/jod.1991.0016

IDEA. (2006). Reforming Electoral Processes. In IIDEA, Electoral Management Design: The International IDEA Handbook. Stockholm, Sweden: International Institute

Jacobs, K., \& Leyenaar, M. (2011). A Conceptual Framework for Major, Minor, and Technical Electoral Reform. West European Politics, 34(3), 495-513. http://dx.doi.org/10.1080/01402382.2011.555977

Katz, S. R. (2007). Comment. Representation, 43(4), 307-314. http://dx.doi.org/10.1080/00344890701574872

Lee, D.-Y., \& Chung, S. H. (2004). Democratic consolidation and electoral reform in Southeast Asia: Philippines, Thailand, and Indonesia. Global Economic Review, 33(4), 51-73. http://dx.doi.org/10.1080/12265080408449862

Leyenaar, M., \& Hazan, R. Y. (2011). Reconceptualising Electoral Reform. West European Politics, 34(3), 437-455. http://dx.doi.org/10.1080/01402382.2011.555974

Lijphart, A. (1994). Electoral Systems and Party Systems: A Study of Twenty-Seven Democracies, $1945-1990$. Oxford: Oxford University Press. http://dx.doi.org/10.1093/acprof:oso/9780198273479.001.0001

Lindberg, S. I. (2010). What Accountability Pressures Do MPs in Africa Face and How Do they respond? Evidence from Ghana. Journal of Modern African Studies, 48(1), $117-142$. http://dx.doi.org/10.1017/S0022278X09990243

Loh, C. (2006). A Unique Feature of the Hong Kong Legislative Council. Hong Kong: Hong Kong University Press.

Lumumba-Kasongo, T. (2005). The problems of liberal democracy and democratic process: Lessons for deconstructing and building Africa democracies. In Lumumba-Kasongo, T. (Ed.), Liberal Democracy and its Critics in Africa: Political Dysfunction and the Struggle for Social Progress (pp. 1-25). London: Zed Books.

NPP. (1993). The Stolen Verdict. Accra: NPP.

Olsen , P. J. (2009). Change and Continuity: An Institutional Approach to Institutions of Democratic Government. European Political Science Review, 1(1), 3-32. http://dx.doi.org/10.1017/S1755773909000022

Oquaye, M. (1995). The Ghanaian Elections of 1992 - A dissenting view. African Affairs, 94, 251-272.

Pilet, J.-B., \& Bol, D. (2011). Party Preferences and Electoral Reform: How Time in Government Affects the Likelihood of Supporting Electoral Change. West European Politics, 34(3), 568-586. http://dx.doi.org/10.1080/01402382.2011.555984

Reed, R. S., \& Thies, M. F. (2001). The Causes of Electoral Reform in Japan. In M. S. Shugart, \& M. P. Wattenberg (Eds.), Mixed-Member Electoral Systems: The Best of Both Worlds? (pp. 152-172). Oxford: Oxford University Press.

Renwick, A. (2010). The Politics of Electoral Reform: Changing the Rules of Democracy. Cambridge: 
Cambridge University Press.

Republic of Ghana, (2012a). Public elections regulations: Biometric verification (Constitutional Instrument 75). Accra: Assembly Press.

Republic of Ghana. (1965). Electoral Provision Act 291. Tema: Ghana Publishing Corporation.

Republic of Ghana. (1969). Constitution of Republic of Ghana 1969. Tema: Ghana Publishing Corporation.

Republic of Ghana. (1992a). Representation of the People Law (PNDCL) 284. Tema: Ghana Publishing Corporation.

Republic of Ghana. (1992b). Constitution of the Fourth Republic of Ghana. Tema: Ghana Publishing Corporation.

Republic of Ghana. (2000a). Political Party Act, 2000 (ACT 574). Accra: Ghana Publishing Company (Assembly Press).

Republic of Ghana. (2000b). Results of Parliamentary Elections. Accra: Assembly Press.

Republic of Ghana. (2008). Results of Parliamentary Elections. Accra: Assembly Press.

Republic of Ghana. (2012b). Results of Parliamentary Elections. Accra: Assembly Press.

Saffu, Y. (2003). The Funding of Political Parties and Election Campaigns in Africa. Funding of political parties and election campaigns. Sweden: IDEA.

Salih, M. A. M., \& Nordlund, P. (2007). Political parties in Africa: Challenges for sustained multiparty democracy. Stockholm: International IDEA.

Sandbrook, R., \& Oelbaum, J. (1999). Reforming the political kingdom: Governance and development in Ghana's fourth republic. Critical perspective. Accra: Center for Democratic Development.

Shiu-Hing, L., \& Wing-Yat, Y. (2010). The Politics of Electoral Reform in Hong Kong. Commonwealth \& Comparative Politics, 39(2), 98-123. http://dx.doi.org/10.1080/713999549

Shugart, M. S. (2008). Inherent and Contingent Factors in Reform Initiation in Plurality Systems. In A. Blais (Ed.), To Keep or to Change First Past the Post? The Politics of Electoral Reform. Oxford: Oxford University Press. http://dx.doi.org/10.1093/acprof:oso/9780199539390.003.0002

Siriboe Report. (1968). Part I and II of the report of the commission of enquiry into electoral and local government reform. Tema: Ghana Publishing Corporation (Assembly Press) Accra.

Smith, D. (2011). The re-demarcation and reapportionment of parliamentary constituencies in Ghana. CDD-Ghana Briefing Papers, 10(2), 1-12.

Tsebelis, G. (2002). Veto Players: How Political Institutions Work. Princeton, NJ: Princeton University Press.

\section{Notes}

Note 1. It was a contract between Ghana Government and STX Engineering \& Construction Limited of South Korea for the construction of 200,000 houses in Ghana in five (5) years, estimated at $\$ 10$ billion in 2009.

Note 2. For instance, the NPP rejected the 2012 presidential elections results and petitioned the Supreme Court to annul the declaration of NDC's John Mahama as winner and uphold the victory of NPP's Akuffo-Addo. According to the NPP, both the EC and NDC colluded to rig the election in favour of the NDC's candidate.

Note 3. The IPAC agreed that every voter should be verified before he/she cast the ballot. The EC made a declaration to the effect that s voter who did not check with the biometric machine would not be allowed to vote.

Note 4. When the NPP's Kufuor created additional 28 constituencies prior to the 2008 elections, the NDC criticized the exercise as a calculated measure to create safe seats in order to control the legislature. The same charge was leveled against the NDC by the NPP when Ata Mills added 45 new constituencies in 2012.

Note 5. The NDC criticized Kufuor for redrawing the electoral boundaries in Kumai metropolis, which split large constituencies such as Bantama, Subin, Oforikrom, Manhyia, among others into two constituencies each in order to disadvantage the NDC in the Asante region.

Note 6. In the Round 4 of the Afrobarometer survey, more than two-thirds of respondents complained of not seeing their MP since the last elections. Of these more than half said they did not vote for the incumbent and think that the MP have not represented their interest in Parliament 
Note 7. Throughut the 1990s, Rawlings constantly antagonized Ghanaian enterprenuers including Mr Appiah Menka whom he described as finaciers of the opposition parties. He publicly called on Ghanaians not to patronize his products because he would use his profict to sponsor the opposition parties.

Note 8 . This method is generally regarded as the panacea to the unequal distribution of parliematry seats in Parliament.

Note 9. The Legislative Council of the Hong Kong Special Administrative Region (LegCo) uses an electoral system known as functional constituencies (FCs) to elect half of its members. The system confers a right to vote on a small percentage of the adult population based on membership or registration in a recognised social, economic, industrial, commercial, political advisory. See Loh, Christine. 2006. A Unique Feature of the Hong Kong Legislative Council. Hong Kong: Hong Kong University Press. p. 59

Note 10. A fundamental weakness in the functional constituency framework is the tendency for the members elected to the legislature to press, first and foremost, their constituency interests, and making national issues secondary. See Loh, Christine. 2006. A Unique Feature of the Hong Kong Legislative Council. Hong Kong: Hong Kong University Press, p. 265.

Note 11. Since the Beijing Platform for Action was inaugurated in 1992, many women advocates have called for electoral reform that promotes women quota in Parliament and political and bureaucratic appointments. In recent times, many civil society groups including the CDD have their voice for an extended system that guarantees the representation of vulnerable groups in politics.

Note 12. All the interviewees agreed to the proposal for the inclusion of the marginalized groups to choose their representatives to Parliament.

Note 13. More than two-thirds of the interviewees except the EC officials supported the proposal.

\section{Copyrights}

Copyright for this article is retained by the author(s), with first publication rights granted to the journal.

This is an open-access article distributed under the terms and conditions of the Creative Commons Attribution license (http://creativecommons.org/licenses/by/3.0/). 